(c) Nedoborenko V.M., Shlykova O.A., Izmailova O.V., Ishcheikin K.E., Kaidashev I.P.

УДК 616.155.194-056.5-055.2

DOI https://doi.org/10.31718/mep.2018.22.3-4.04

\title{
SUBCUTANEOUS ADIPOSE TISSUE IN FEMALE PATIENTS WITH IRON DEFICIENCY ANEMIA AND OBESE WOMEN DOES NOT DIFFER IN THE EXPRESSION OF IKBA*
}

\author{
Nedoborenko V.M., Shlykova O.A., Izmailova O.V., Ishcheikin K.E., Kaidashev I.P. \\ Ukrainian Medical Stomatological Academy
}

Prerequisites and objective: Abdominal obesity is a common metabolic disease characterized by excessive accumulation of white adipose tissue, with excessive production of inflammatory mediators that activate transcriptional nuclear factors, in particular the nuclear factor kB. Hepcidin is the main hormone in the systemic regulation of iron. Its expression increases with elevated level of pro-inflammatory cytokines, as a result of which the concentration of iron in the blood plasma decreases, which reliably results in the activation of NF-kB. Therefore, the aim of the research was to determine the level of expression of IKßa in subcutaneous adipose tissue in iron deficiency anemia concurrent with obesity. Methods: The study included 40 female women. Hemogram parameters, parameters of iron metabolism (serum iron, ferritin, hepcidin, total iron binding ability of serum, saturation of transferrin by iron) in serum and level of expression of the IkBa gene in subcutaneous adipose tissue were evaluated. Research results. The examined women had an average age of $40.3 \pm 7.59$ years. In the distribution of patients due to the cause and degree of severity of IDA, there was no reliable difference between the groups. The control group consisted of 10 obese women without IDA. Expression of IkBa by subcutaneous adipose tissue in female patients with IDA with and without obesity compared with the control group did not display a significant difference between the groups $(p<0.05)$. In the course of correlation analysis, the expression of IkBa by subcutaneous adipose tissue to BMI, iron and hemogram rates did not have a correlated significance. Conclusion. Subcutaneous adipose tissue in women with iron deficiency anemia with and without obesity compared with obese women has no difference in expression of IkBa.

Key words: IkBa expressions, obesity, anemia.

Ожиріння органів черевної порожнини - це загальне метаболічне захворювання, що характеризується надмірним накопиченням білої жирової тканини, з надмірним виробництвом медіаторів запалення, які активують транскрипційні ядерні фактори, зокрема ядерний фактор кВ. Гепсидин є основним гормоном системної регуляції заліза. Його експресія зростає з підвищеним рівнем прозапальних цитокінів, внаслідок чого концентрація заліза у плазмі крові знижується, що надійно призводить до активації NF-kB. Тому метою дослідження було визначення рівня експресії ІКВа в підшкірній жировій тканині при залізодефіцитній анемії, що супроводжується ожирінням. Дослідження включало 40 жінок. Оцінювали параметри гемограми, параметри метаболізму заліза (сироваткове залізо, феритин, гепсидин, загальна залізозв'язувальна здатність сироватки, насичення трансферину залізом) в сироватці та рівень експресії гену IкВа в підшкірній жировій тканині. Опитані жінки мали середній вік 40,3 \pm 7,59 років. У розподілі пацієнтів через причину та ступінь тяжкості залізодефіцитної анемії була відсутня достовірна різниця між групами. Контрольну групу склали 10 пацієнтів із ожирінням, які не мали залізодефіцитної анемії. Експресія IкВа підшкірною жировою тканиною у пацієнтів з залізодефіцитною анемією з ожирінням та без нього порівняно з контрольною групою не відрізнялася значною різницею між групами ( $p<0,05)$. У ході кореляційного аналізу експресія IkBa підшкірною жировою тканиною до показників залізодефіцитної анемії, заліза та гемограми не мала корельованого значення. Підшкірна жирова тканина у жінок з дефіцитом заліза з і без ожиріння в порівнянні з жінками з ожирінням не має різниці в експресії IkBa.

Ключові слова: експресія IkBa, ожиріння, анемія.

\section{Introduction}

Abdominal obesity is a common metabolic disease characterized by excessive accumulation of white adipose tissue.

Subcutaneous adipose tissue is infiltrated by numerous immune cells, primarily macrophages, which account for up to $40 \%$ of all fatty tissue cells [1] and are the main source of inflammatory mediators in the fatty tissues of humans and animals. Pro-inflammatory cytokines affect the intracellular pathways regulating inflammation by activating transcriptional nuclear factors, in particular the nuclear factor kB (NF-kB), which is the most important pro-nuclear nuclear transcription factor that corresponds to most of the external and internal stimuli and provokes inflammation by activating or sup- pressing the transcription of numerous genes involved in the inflammatory reaction [2].

Iron plays an important role in immunological surveillance due to its stimulating and differentiating properties on the immune system. Excessive concentration of iron in macrophages reduced the level of phagocytosis, respiratory burst and cytokine expression - the effects that are probably mediated by iron toxicity. On the other hand, in non-toxic concentrations, iron contributes to the differentiation of macrophages, and treatment with iron chelators inhibits the expression of NF-KB activated by lipopolysaccharides, tumor necrosis factor- $\alpha$ and interleukin-6 [3]. The addition of ionized iron to the macrophage culture of the liver caused activation of IKK (a complex that is a critical point of this signaling pathway) [4], which con-

\footnotetext{
* To cite this English version: V.M. Nedoborenko, O.A. Shlykova, O.V. Izmailova, K.E. Ishcheikin, I.P. Kaidashev. Subcutaneous adipose tissue in female patients with iron deficiency anemia and obese women does not differ in the expression of IkBa // Problemy ekologii ta medytsyny. - 2018. - Vol 22, № 3-4. - P. 14-17.
} 
firmed the role of iron as an independent agonist and potential signaling molecule for activating IKK [3].

Hepcidin is the main hormone in the systemic regulation of iron. Hepcidin is a negative regulatory hormone, whose expression increased with elevated level of proinflammatory cytokines and iron. The mechanism of exposure to hepcidin was detected in binding with ferroportin, which led to its internalization and degradation [5]. As a result, the content of circulating iron level was reduced and the suppression of its export from macrophages was intensified by the same mechanism that reliably resulted in the activation of NF-kB.

However, at present there are no data demonstrating the relationship between iron, hepcidin and NF-kB human adipose tissue in vivo. The activation of NF-kB may be evidenced by changes in the expression of its inhibitor, IkBa [6], therefore, the aim of our study was to determine the level of expression of IK $\beta \alpha$ in subcutaneous adipose tissue in iron deficiency anemia concurrent with obesity.

\section{Materials and methods}

The study was conducted after authorization by the Bioethics Commission of Ukrainian Medical Stomatological Academy, and all the examined subjects voluntarily signed the informed consent.

A total of 40 female patients with iron deficiency anemia (IDA) (30 women with concomitant obesity and 10 without obesity) were examined. They were treated at the out-patient department of the City clinical hospital in Poltava from March 2016 to January 2017. The control group consisted of 10 obese women without IDA.

The inclusion criteria were the presence of iron deficiency anemia based on: hemoglobin level $(\mathrm{Hb}) \leq 120 \mathrm{~g} / \mathrm{L}$ for women, signs of microcytosis and anemia (Mean Corpuscular Volume (MCV) $\leq 80 \mathrm{fl}$, Mean Corpuscular Hemoglobin $(\mathrm{MCH}) \leq 27,5 \mathrm{pg}$, Mean Corpuscular Hemoglobin

Concentration $(\mathrm{MCHC}) \leq 335 \mathrm{~g} / \mathrm{L}$, in the presence of serum iron level $(\mathrm{SI})<11.5 \mu \mathrm{mol} / \mathrm{L}$, total serum iron binding capacity (TSIBC) $>72 \mu \mathrm{mol} / \mathrm{L}$, saturation of transferrin with iron (NTZ) $<15 \%$ and ferritin level $\leq 12 \mathrm{ng} / \mathrm{ml}$ in serum.

The blood parameters were determined using the BC 3000 Plus Mindray, Shenzhen Mindray Bio-Medical Electronics Co., Ltd., China.

Determination of iron level in serum and total serum iron binding capacity was carried out with sets of reagents of SpinLab Ltd, Ukraine. Saturation of transferrin with iron was determined by the method of calculating the content of the SI / TSIBC * $100 \%$.

The level of ferritin (LLC «Alkor-Bio», Russian Federation), hepcidin (Peninsula Laboratories, LLC, USA) in blood serum was determined by the method of immunoassay analysis.

The level of expression of the lkBa gene was determined in the subcutaneous fat using the real-time PCR method. The material was obtained by thin-layer aspiration puncture biopsy, samples were stored at $-70^{\circ} \mathrm{C}$ until RNA extraction. The total RNA was isolated from the biological specimen using a set of "RIBO-sol-V reagents" (AmpliSens, Russia). To obtain cDNA, a set of reagents was used for the reverse transcription reaction (SYNTOL, Russia). The reaction mixture contained: $10 \times$ reverse transcriptase buffer, 5 $\mathrm{mM}$ deoxynucleotide triphosphate, $15 \mathrm{U} / \mathrm{ml}$ oligo primer (dT) 15, 50 units/ $\mu$ l of inverse mRNA-RT transcriptase, 5 units/ $\mu$ l RNase inhibitor, 1-2 $\mu \mathrm{g}$ total RNA, and deionizing water free of RNase. Determination of the expression of the IkBa gene was carried out in real time using a DT-Light detecting amplifier ("DNA-Technology", Russia) in the reaction mixture. As a reference gene, the Glyceraldehyde-3Phosphate Dehydrogenase (GAPDH) gene was used. For data analysis, a relative Ct method was used with the calculation of the formula: $2-\Delta \mathrm{Ct}$.

Table 1. Primers for determining the expression of the $\mathrm{lkBa}$ gene [7]

\begin{tabular}{|c|c|}
\hline Gene & Sequence of primers \\
\hline \multirow{2}{*}{ IkBa } & F: 5' - GGC TGA AGA AGG AGC GGC TA - 3' \\
& R: 5' - CCA TCT GCT CGT ACT CCT CG -3' \\
\hline \multirow{2}{*}{ GAPDH } & F: 5' - GGC CTC CAA GGA GTA AGA CC - 3' \\
& R: 5' - AGG GGA GAT TCA GTG TGG TG - 3' \\
\hline
\end{tabular}

Furthermore, all patients were evaluated for the level of total protein, total bilirubin, ALT, AST, creatinine, endoscopic and X-ray examination of the gastrointestinal tract, to exclude ulcerative and inflammatory diseases at the time of the study.

For all patients, the examination included measurements of anthropometric indicators: height, body weight, waist and hip circumference, body mass index (BMI). The index was calculated as the ratio of body weight in kilograms $(\mathrm{kg})$ to the square of height in meters (m2). Adult obesity was established according to the WHO definition based on $(B M I) \geq 30 \mathrm{~kg} / \mathrm{m} 2$.

The distribution of adipose tissue is determined by the coefficient of the waist circumference / hip circumference (WC / HC). The value of WC / HC in women > 0.85 indicated the abdominal type of obesity.

The study excluded patients who at the time of the study had been taking iron preparations during the last 3 months, non-steroidal anti-inflammatory drugs more than 3 times a week during the last 6 months, patient with conditions of significant bleeding over the past 6 months, oncopathology, autoimmune diseases, acute and chronic diseases that can lead to tissue hypoxia, chronic renal failure, chronic liver disease with hepatocellular insufficiency, vegetarianism, pregnancy and lactation.

The static processing of the obtained data was performed using the software package SPSS 17.0. The reliability of the discrepancies $(p)$ of the anthropometric data and hematological parameters was evaluated by the one-way analysis of variance for independent groups (ANOVA). Relationships in groups were evaluated using Pearson correlation analysis. For all types of analysis, statistically significant differences were considered at $p<0.05$.

\section{Results}

The examined women had an average age of $40.3 \pm$ 7.59 years. In the distribution of patients due to the cause and degree of severity of IDA, there was no reliable difference between the groups.

In the analysis of anthropometric data of women, the group with IDA and obesity had statistically higher BMI compared to the group with IDA and without obesity $(p<0.05)$ and had no statistically significant differences compared with the control group ( $p>0.05)$. The analysis of the ratio of WC / $\mathrm{HC}$ revealed that all the examined patients in this group had an abdominal type of adipose tissue deposit. 
ToM 22, N 3-4 2018 p.

Table 2. Indices of hemogram and iron metabolism parameters in women with IDA with and without obesity $(M \pm S D)$

\begin{tabular}{|c|c|c|c|}
\hline Indicator, unit of measurement & $\begin{array}{c}\text { Group with IDA and obe- } \\
\text { sity, }(\mathrm{n}=30)\end{array}$ & $\begin{array}{c}\text { Group with IDA and with- } \\
\text { out obesity, }(\mathrm{n}=10)\end{array}$ & Control group, $(\mathrm{n}=10)$ \\
\hline Erythrocytes, $10^{\mathrm{9}} / \mathrm{l}$ & $3.98 \pm 0.26^{\mathrm{a}}$ & $4.0 \pm 0.2^{\mathrm{a}}$ & $4.3 \pm 0.2^{\mathrm{a}}$ \\
\hline $\mathrm{Hb}, \mathrm{g} / \mathrm{l}$ & $90.4 \pm 10.3^{\mathrm{a}}$ & $91.6 \pm 8.65^{\mathrm{a}}$ & $129 \pm 3.8^{\mathrm{B}}$ \\
\hline $\mathrm{MCV}, \mathrm{fl}$ & $71.6 \pm 5.1^{\mathrm{a}}$ & $72.0 \pm 4.8^{\mathrm{a}}$ & $88.4 \pm 4.6^{\mathrm{B}}$ \\
\hline $\mathrm{MCHC}, \mathrm{g} /$ & $316.6 \pm 19.42^{\mathrm{a}}$ & $316.3 \pm 15.8^{\mathrm{a}}$ & $338.9 \pm 6.0^{\mathrm{B}}$ \\
\hline $\mathrm{MCH}, \mathrm{g} /$ & $22.6 \pm 1.95^{\mathrm{a}}$ & $22.7 \pm 1.83^{\mathrm{a}}$ & $29.9 \pm 1.3^{\mathrm{B}}$ \\
\hline $\mathrm{Fe} \mathrm{F}^{3+}, \mu \mathrm{mol} / \mathrm{I}$ & $5.6 \pm 2.38^{\mathrm{a}}$ & $7.3 \pm 1.4^{\mathrm{a}}$ & $15.3 \pm 2.34^{\mathrm{B}}$ \\
\hline $\mathrm{TSIBC}, \mu \mathrm{mol} / \mathrm{I}$ & $74.5 \pm 2.0^{\mathrm{a}}$ & $73.8 \pm 1.3^{\mathrm{a}}$ & $61.0 \pm 4.96^{\mathrm{B}}$ \\
\hline $\mathrm{STI} \%$ & $7.7 \pm 3.30^{\mathrm{a}}$ & $9.8 \pm 2.0^{\mathrm{a}}$ & $25.0 \pm 2.5^{\mathrm{B}}$ \\
\hline Ferritin, $\mathrm{ng} / \mathrm{ml}$ & $4.7 \pm 2.68^{\mathrm{a}}$ & $3.5 \pm 2.93^{\mathrm{a}}$ & $29.7 \pm 10.8^{\mathrm{B}}$ \\
\hline Hepcidin, $\mathrm{ng} / \mathrm{ml}$ & $16.6 \pm 11.9^{\mathrm{a}}$ & $25.4 \pm 8.6^{\mathrm{B}}$ & $14.4 \pm 12.0^{\mathrm{a}}$ \\
\hline
\end{tabular}

Note: $a a, b b=$ no significant difference between the groups $(p>0.05)$; $a b, b a=$ significant difference between groups $(p<0.05)$.

Indicators of $\mathrm{Hb}, \mathrm{MCV}, \mathrm{MCHC}, \mathrm{MCH}, \mathrm{SI}, \mathrm{STI}$ and ferritin in the groups of women with IDA without and with obesity were significantly lower $(p<0.05)$ compared with the control group and did not differ significantly between these parameters $(p>0.05)$. On the contrary, TSIBC in the groups of women with IDA without and with obesity was significantly higher $(p<0.05)$ compared with the control group and had a significant difference $(p>0.05)$ (Table 1).

Hepcidin in the serum was higher in women with IDA without obesity $(p<0.05)$ compared to women with obesity and control group who did not have significant differences $(p>0.05)$ (Table 1).

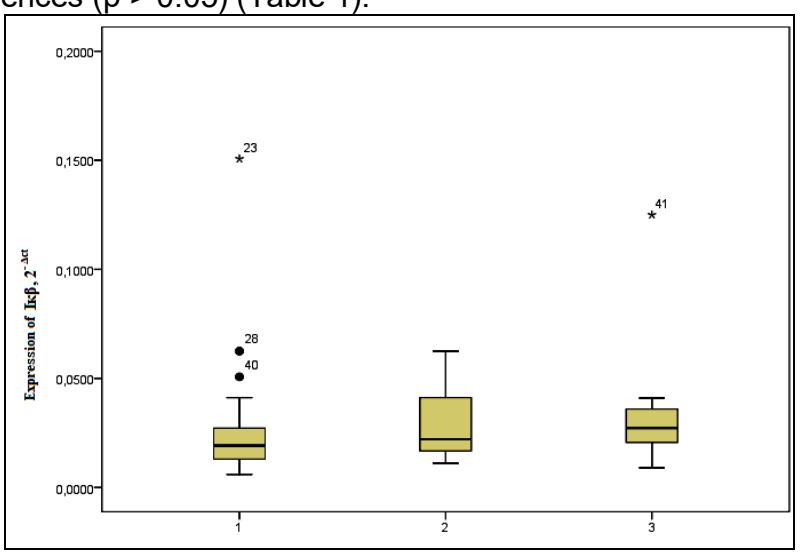

Figure 1. Expression of $I k B \alpha, 2-\Delta c t$ in female patients with IDA and obesity - (1), IDA without obesity - (2) and control group (3).

Expression of $\mathrm{IkBa}$ subcutaneous adipose tissue in female patients in IDA with and without obesity compared with the control group did not have a significant difference between the groups $(p<0.05)$ (Fig. 1).

In the course of correl1ation analysis, the expression of $\mathrm{IkBa}$ by subcutaneous adipose tissue to BMI, iron metabolism and hemogram rates did not have a correlated reliable significance.

\section{Discussion}

Our study showed the condition of iron metabolism, namely its deficiency, in absolute (true) IDA ( $\mathrm{Hb}, \mathrm{MCV}$, $\mathrm{MCHC}, \mathrm{MCH}$ ) [8] using a rather wide range of indicators of its metabolism (SI, STI, TSIBC, ferritin and hepcidin) [9]. As is evident, there was no statistically significant difference between the hemogram parameters and the markers of iron homeostasis among the study groups, except for the hepcidin, which had a higher level in the group with IDA without obesity $(25.4 \pm 8.6 \mathrm{ng} / \mathrm{ml})$, as compared with the group of IDA with obesity and control group $(16.6 \pm 11.9 \mathrm{ng} / \mathrm{ml}$ and $14.4 \pm 12.0 \mathrm{ng} / \mathrm{ml}$, re- spectively), but still within the range of reference value. This fact may be explained by the presence of a significant degree of obesity for increased hepcidin and inflammatory markers, as established by Cheng et al. and Karl et al.[10, 11].

NF-kB is a transcription factor, which is the most important pro-inflammatory nuclear transcription factor, one of the key regulators of immunity, stress reactions, apoptosis and cell differentiation. Its activation is observed under the influence of numerous stimuli, both intracellular and extracellular ones [12]. Intracellular free iron was involved in a number of these stimuli activation [13].

Our study was based on two reliable facts: the first one - obesity has been studied in recent years as a condition of chronic low-intensity inflammation with excessive production of inflammatory mediators, in particular IL-6 and CRP [14], followed by activation in the expression of the hepcidin gene [15], which leads to the accumulation of iron trace element in macrophages and according to Shigang Xiong et al.[16], iron acts as a pro-inflammatory effector molecule by selective induction of intracellular signaling for NF-kB; the second one - IDA is the final degree of iron deficiency, characterized by both external and intracellular decrease in iron concentration, and according to previous studies with chelated iron, the reduction of free intracellular iron generally inhibits the activation of NF-kB [17].

However, despite these assumptions, our results show that the expression of IkBa by subcutaneous adipose tissue in female patients in IDA with and without obesity, as well as obese women do not display a significant difference between groups $(0.26 \pm 0.2-2 \Delta \mathrm{ct}, 0.3 \pm$ 0.1-2 $\Delta$ ct, $0.35 \pm 0.3-2 \Delta$ ct, respectively).

In addition, no significant correlations were found between expression of the IkBa gene, BMI, iron metabolism, and morphology of erythrocytes.

This study is the first attempt to describe the expression of $\mathrm{lkBa}$ by subcutaneous adipose tissue in female patients in IDA as compared with women only with obesity in vivo. However, it is well understood that adipose tissue is not homogeneous [18]. Therefore, despite the reported data that IkBa has no significant difference between the study groups in women, we cannot rule out the possibility that visceral adipose tissue has no effect on the regulation of systemic or localized iron metabolism. Moreover, subcutaneous adipose tissue may have a protective effect in many pathological conditions.

Conclusion. Subcutaneous adipose tissue in female patients with iron deficiency anemia with and without obesity has no difference in expression of $\mathrm{IkBa}$ as compared with obese women. 


\section{References}

1. Lee, B-C, \& Lee, J. Cellular and Molecular Players in Adipose Tissue Inflammation in the Development of Obesityinduced Insulin Resistance. Biochimica et Biophysica Acta. 2014; 1842(3): 446-462.

2. Kaidashev IP. Nf-kb-signalizatsiya kak osnova razvitiya sistemnogo vospaleniya, insulinorezistentnosti, lipotoksichnosti, sakharnogo diabeta 2-go tipa i ateroskleroza. Mezhdunarodnyy endokrinologicheskiy zhurnal. 2011; 3 (35): 35-45

3. Xiong $\mathrm{S}$, She $\mathrm{H}$, Takeuchi $\mathrm{H}$. Signaling Role of Intracellular Iron in NF-kB Activation. J. Biol. Chem. 2003; 278: 1764617654.

4. Oeckinghaus A, Ghosh S. The NFkappaB family of transcription factors and its regulation. Cold Spring Harb. Perspect. Biol. 2009; 1(4): 28 - 34

5. Nemeth E, Tuttle MS, Powelson J, Vaughn MB, Donovan A, Ward DM, Ganz T, Kaplan J. Hepcidin regulates cellular iron efflux by binding to ferroportin and inducing its internalization. Science. 2004; 306: 2090-2093.

6. Tak PP, Firestein GS. NF-kB: a key role in inflammatory diseases. Journal of Clinical Investigation. 2001; 107(1):711.

7. Zhou C, Tabb MM, Nelson EL, et al. Mutual repression between steroid and xenobiotic receptor and NF-KB signaling pathways links xenobiotic metabolism and inflammation. The Journal of Clinical Investigation. 2006; 116(8): 2280-2289.

8. Muñoz M, García-Erce JA, Remacha ÁF. Disorders of iron metabolism. Part II: iron deficiency and iron overload. Journal of Clinical Pathology 2011; 64: 287-296.

9. Camaschella C. Iron-Deficiency Anemia. N Engl J Med. 2015; 372:1832-1843.
10. Cheng HL, Bryant CE, Rooney KB et al. Iron, hepcidin and inflammatory status of young healthy overweight and obese women in Australia. PloS One. 2013; 8(7):e68675.

11. Karl JP, Lieberman HR, Cable SJ et al. Poor iron status is not associated with overweight or overfat in non-obese pre-menopausal women. J Am Coll Nutr. 2009; 28(1): 3742.

12. Kădashev IP. NF-kB activation as a molecular basis of pathological process by metabolic syndrome. Fiziol $\mathrm{Zh}$. 2012; 58(1):93-101. Review. Ukrainian.

13. Wang L, Cherayil BJ. Ironing Out the Wrinkles in Host Defense: Interactions between Iron Homeostasis and Innate Immunity. Journal of Innate Immunity. 2009;1(5):455-464.

14. Greenberg AS, Obin MS. Obesity and the role of adipose tissue in inflammation and metabolism. Am J Clin Nutr. 2006; 83:461-465

15. Bekri S., Gual P. Increased adipose tissue expression of hepcidin insevere obesity is independent from diabetes and NASH / Soumeya Bekri, // Gastroenterology. 2006; 131: 788-796.

16. Xiong $\mathrm{S}$, She $\mathrm{H}$, Tsukamoto $\mathrm{H}$. Signaling role of iron in NFkappa B activation in hepatic macrophages. Comparative Hepatology. 2004; 3(Suppl 1):S36.

17. She $\mathrm{H}$, Xiong $\mathrm{S}$, Lin $\mathrm{M}$, Zandi E, Giulivi C, Tsukamoto $\mathrm{H}$ : Iron activates NF-B in Kupffer cells. Am J Physiol Gastrointest Liver Physiol. 2002; 283:G719-G726.

18. Smith S. R., Lovejoy J. C., Greenway F. et al., Contributions of total body fat, abdominal subcutaneous adipose tissue compartments, and visceral adipose tissue to the metabolic complications of obesity. Metabolism. 2001; 50(4): 425-435.

Матеріал надійшов до редакції 04.09.2018 